
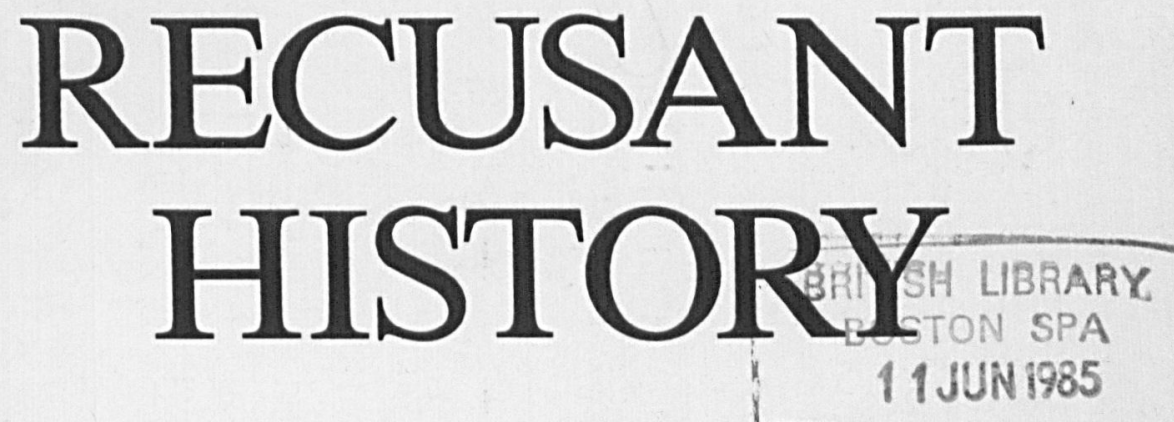

A Journal of Research 7331.155 in Post-Reformation

Catholic History in the British Isles

Vol. 17 , No. 3

May 1985

EDMUND CAMPION'S ALLEGED INTERVIEW Marion Colthorpe WITH QUEEN ELIZABETH IN 1581

THE RELATION BETWEEN ROBERT SOUTHWELL'S NEO-LATIN AND ENGLISH POETRY

THE PRACTICE AND PROBLEMS OF

RECUSANT DISARMING, 1585-1641

CANON HENRY TAYLOR, SPANISH HABSBURG DIPLOMAT

'THAT DAMNED BOOKE': THE GROUNDS OF OBEDIENCE AND GOVERNMENT (1655), AND THE DOWNFALL OF THOMAS WHITE

BLANCO WHITE'S EVIDENCE

ULTRAMONTANISM IN YORKSHIRE, 1850-1900

THE CALDEY MONKS AND THE CATHOLIC PRESS, 1905-1913

Brian Oxley

B. W. Quintrell

Albert J. Loomie, S.J.

B. C. Southgate

NEWSLETTER 1985

Martin Murphy

Jennifer F. Supple

Rene M. Kollar, O.S.B.

\title{
THE CATHOLIC RECORD SOCIETY
}

